DOI 10.22460/jpmi.v1i3.219-228

\title{
PENGARUH PENDEKATAN REALISTIK TERHADAP KEMAMPUAN KOMUNIKASI DAN SELF CONFIDENCE SISWA SMP
}

\author{
Susi Martini ${ }^{1}$, Dila Padilah ${ }^{2}$, Tina Rosyana ${ }^{3}$, Euis Eti Rohaeti ${ }^{4}$ \\ 1,2,3,4 IKIP Siliwangi, Jl. Terusan Jenderal Sudirman, Cimahi, Jawa Barat, Indonesia \\ 1hsusi.sm@gmail.com, ${ }^{2}$ dilapadilah23@gmail.com, ${ }^{3}$ tinarosyana@gmail.com, ${ }^{4}$ e2rht@yahoo.com
}

\begin{abstract}
This study aims to examine the achievement of communication skills and mathematical self confidence of students who use a realistic approach compared to using ordinary learning. The method used in this study is the experimental method, with the preview-postes experimental control group design. The population in this study is all junior high school students in West Bandung regency, while the sample of the research is as many as two classes of class VII are randomly selected from all the existing class VII. then both classes are selected to be the experimental class and control class. The experimental class gained learning through the Realistic approach and the control class gained regular learning. The instrument used in this research is a matter of communication ability test and non test of Self Confidence. Data of research result is analyzed quantitatively by using statistical test ( $t$ test). The conclusion obtained as follows: 1) The ability of mathematical communication of students who get learning with realistic approach is better than students who get regular learning; 2 ) The ability of self confidence students who gain learning with a realistic approach is better than students who get regular learning.
\end{abstract}

Keywords: Mathematical Communication, Self Confidence, Realistic Approach

\begin{abstract}
Abstrak
Penelitian ini bertujuan untuk menelaah pencapaian kemampuan komunikasi dan Self Confidence matematis siswa yang menggunakan pendekatana realistik dibandingkan dengan yang menggunakan pembelajaran biasa. Metode yang digunakan dalam penelitian ini yaitu metode eksperimen, dengan desain kelompok eksperimen-kontrol pretes-postes. Populasi pada penelitian ini adalah seluruh siswa SMP di Kabupaten Bandung Barat, sedangkan sampel penelitiannya adalah sebanyak dua kelas dari kelas VII yang dipilih secara acak dari seluruh kelas VII yang ada. kemudian kedua kelas tersebut dipilih menjadi kelas eksperimen dan kelas kontrol. Kelas eksperimen memperoleh pembelajaran melalui pendekatan Realistik dan kelas kontrol memperoleh pembelajaran biasa. Instrumen yang digunakan dalam penelitian ini berupa soal tes kemampuan komunikasi dan dan soal non tes Self Confidence. Data hasil penelitian dianalisis secara kuantitatif dengan menggunakan uji statistik (uji t). Kesimpulan yang diperoleh sebagai berikut: 1) Kemampuan komunikasi matematik siswa yang memperoleh pembelajaran dengan pendekatan realistik lebih baik daripada siswa yang memperoleh pembelajaran biasa; 2) Kemampuan self confidence siswa yang memperoleh pembelajaran dengan pendekatan realistik lebih baik daripada siswa yang memperoleh pembelajaran biasa.
\end{abstract}

Kata Kunci: Komunikasi Matematis, Self Confidence, Pendekatan realistic

How to cite: Martini, S. Padilah, D., Rosyana, T., \& Rohaeti., E. E. (2018). Pengaruh Pendekatan Realistik terhadap Kemampuan Komunikasi dan Self Confidence Siswa SMP. JPMI - Jurnal Pembelajaran Matematika Inovatif, 1 (2), 149-156.

\section{PENDAHULUAN}


Matematika merupakan salah satu ilmu pengetahuan yang memegang peranan penting dalam kehidupan manusia. Dalam kehidupan sehari-hari, matematika selalu dapat kita temui mulai dari matematika yang sederhana hingga yang kompleks. Matematika sebagai ilmu pengetahuan yang diperoleh dari bernalar adalah suatu ilmu dasar dan salah satu disiplin ilmu yang sangat besar pengaruhnya terhadap kemajuan dan perkembangan ilmu pengetahuan. (Rosyana, dan Sari, 2015).

Melihat pentingnya matematika dalam kehidupan sehari-hari, maka matematika perlu diajarkan. Cockroft (Haji, 2012) mengemukakan bahwa matematika perlu diajarkan karena: 1) Selalu digunakan dalam segala segi kehidupan, 2) Semua bidang studi memerlukan keterampilan matematika yang sesuai, 3) Merupakan sarana komunikasi yang kuat, singkat, dan jelas, 4) Dapat digunakan untuk menyajikan informasi dalam berbagai cara, 5) Meningkatkan kepuasan terhadap usaha memecahkan masalah yang menantang. Hal ini diwujudkan melalui proses pembelajaran matematika.

Tujuan pembelajaran matematika yang dirumuskan KTSP (Suparno, 2001:346) menyatakan bahwa belajar matematika bertujuan agar peserta didik mampu memahami konsep matematika, menggunakan penalaran, pemecahan masalah, mengomunikasikan gagasan dengan symbol, tabel, diagram atau media lain untuk memperjelas keadaan atau masalah serta memiliki sikap menghargai kegunaan matematika dalam kehidupan. Untuk mencapai tujuan pembelajaran matematika, salah satu aspek yang harus dikuasai siswa adalah kemampuan komunikasi matematis.

Kemampuan komunikasi matematik meliputi kemampuan: menyatakan suatu situasi ke dalam bahasa matematik, symbol, idea, dan model matematika; menjelaskan dan membaca secara bermakna, menyatakan, memahami, menginterpretasikan, dan mengevaluasi suatu idea matematika dan sajian matematika secara lisan, tulisan, atau secara visual; mendengarkan, mendiskusikan, dan menulis tentang matematika; dan menyatakan suatu argumen dalam bahasanya sendiri. Analisis diatas juga melukiskan bahwa kemampuan komunikasi matematik memiliki peran penting sebagai representasi kemampuan pemahaman siswa terhadap konsep matematik, masalah sehari-hari, dan penerapan konsep matematika dalam disiplin ilmu lain. Melainkan komunikasi matematik siswa bertukar dan saling menjelaskan idea atau pemahaman mereka kepada temannya. (Hendriana, Sumarmo, Rohaeti: 2013).

Ada dua alasan kemampuan komunikasi matematis penting untuk dikembangkan. Pertama, matematika merupakan sebuah bahasa bagi matematika itu sendiri. Matematika merupakan alat berpikir yang membantu kita untuk menemukan pola, memecahkan masalah dan menarik kesimpulan, juga sebuah alat untuk mengomunikasikan pikiran kita tentang berbagai ide dengan jelas, tepat dan ringkas. Kedua, pembelajaran matematika merupakan aktivitas social. Aktivitas ini meliputi komunikasi antara guru dengan siswa maupun siswa dengan siswa. Komunikasi dengan teman sebaya depat membantu siswa lebih memahami materi karena dengan teman sebayanya siswa dapat mengungkapkan materi matematika dengan bahasa informal yang lebih mudah dipahami. Dengan komunikasi, siswa dapat memperoleh pengetahuan, mengungkapkan ide-ide yang mereka miliki.

Dalam mengembangkan kemampuan matematik khususnya kemampuan komunikasi, seorang peserta didik harus memiliki sikap yakin dan percaya akan kemampuan sendiri sehingga terhindar dari rasa cemas dan ragu. Sikap tersebut dapat diartikan sebagai daya juang seseorang dalam memecahkan permasalahan yang sedang dihadapi (Hidayat, 2017; Rosita, 2017). 
Salah satu sikap dalam memecahkan permasalahan tersebut yaitu kepercayaan diri (Self Confidence). Kepercayaan diri yang dimiliki setiap individu dalam memandang dirinya dengan mengacu pada konsep diri. Selain itu kepercayaan diri juga akan memberikan motivasi terhadap pencapaian keberhasilan seseorang dalam memecahkan permasalahan yang sedang dihadapi. Sehingga semakin tinggi kepercayaan seseorang terhadap kemampuan diri sendiri, semakin kuat pula semangat untuk menyelesaikan pekerjaannya. (Hendriana, 2014).

Selain kemampuan komunikasi dan self confidence siswa perlu didukung dengan pembelajaran aktif dan lebih bermakna. Salah satu pembelajaran inovatif adalah pembelajaran menggunakan pendekatan realistik. Ide utama pendekatan realistik yaitu siswa berkesempatan menemukan kembali (reinvent) ide/konsep matematika dengan bimbingan orang dewasa melalui penjelajahan situasi. Dan paradigma ini membawa konsekuensi perubahan mendasar dalam proses pembelajaran. Karena perubahan tersebut guru adalah teman belajar, siswa individu yang aktif dan berkemampuan membangun pengetahuannya sendiri. Siswa berkesempatan menemukan konsep matematika melalui berbagai soal kontekstual. Bermatematika secara progressif adalah bermatematika secara horizontal dan vertikal (secara horizontal siswa mampu mengidentifikasi soal kontekstual hingga mentransfer ke dalam bentuk matematika, secara vertical siswa menyelesaikan bentuk matematika formal/non formal menggunakan konsep, operasi, dan prosedur matematika).

Penelitian ini merupakan hasil observasi. Tujuan penelitian ini untuk menelaah kemampuan komunikasi matematis dan Self Confidence siswa kelas VII SMP di Kabupaten Bandung Barat pada materi Himpunan. Ketika kemampuan komunikasi siswa telah diketahui, selanjutnya guru perlu merancang pembelajaran yang memfasilitasi dan membiasakan siswa untuk melakukan komunikasi metamatis, sehingga kemampuan siswa tersebut dapat meningkat.

\section{METODE}

Metode yang di gunakan dalam penelitian ini adalah metode eksperimen, dengan desain kelompok ekseperimen-kontrol pretes-postes. Pada jenis desain eksperimen ini terjadi pengelompokan subjek secara acak, adanya pretes dan postes. Kelas eksperimen yaitu kelas yang mendapatkan pembelajaran dengan pendekatan Realistik. Kelas control yaitu kelas yang mendapatkan pembelajaran biasa.

Desain penelitiannya (Ruseffendi, 2010:50) berbentuk:

$\begin{array}{llll}\text { A } & \mathrm{O} & \mathrm{X} & \mathrm{O} \\ \mathrm{A} & \mathrm{O} & & \mathrm{O}\end{array}$

Keterangan:

A : Sampel penelitian dipilih secara acak kelas.

$\mathrm{O} \quad$ : Pretes $=$ postes (tes kemampuan komunikasi matematis).

$\mathrm{X} \quad$ : Perlakuan pembelajaran dengan pendekatan Realistik.

Populasi pada penelitian ini adalah seluruh siswa di salah satu SMP di Kabupaten Bandung Barat semester genap Tahun Pelajaran 2017-2018. Sampel yang diambil dalam penelitian ini adalah siswa kelas VII. Dari beberapa kelas VII, kemudian dipilih secara secara acak kelas dua kelas sebagai kelas eksperimen dan kelas kontrol. Instrumen yang digunakan adalah instrument tes berbentuk urairan untuk mengukur kemampuan komunikasi dan penilaian matematis siswa. 


\section{HASIL DAN PEMBAHASAN}

\section{Hasil}

\section{a. Analisis Hasil Penelitian Menggunakan Uji Statistik}

Pada bagian ini disajikan data hasil penelitian serta analisis menggunakan uji statistik. Data deskriptif hasil penelitian sebelum dan sesudah pembelajaran disajikan dalam tabel 1 berikut:

Tabel 1 rekapitulasi hasil pretest postest dan gain kemampuan komunikasi matematik

\begin{tabular}{cccc}
\hline Kelas & Tes & statistik & Komunikasi matematik \\
\hline \multirow{3}{*}{ Eksperimen } & Pretes & $\overline{\boldsymbol{x}}$ & 10,20 \\
\cline { 2 - 4 } & & $\boldsymbol{s}$ & 2,92 \\
\cline { 2 - 4 } & \multirow{2}{*}{ Postes } & $\overline{\boldsymbol{x}}$ & 22,60 \\
\cline { 3 - 4 } & & $\boldsymbol{s}$ & 4,73 \\
\cline { 3 - 4 } & \multirow{2}{*}{ Pretes } & $\overline{\boldsymbol{x}}$ & 9,67 \\
\cline { 3 - 4 } & & $\boldsymbol{s}$ & 2,51 \\
\cline { 3 - 4 } & \multirow{2}{*}{ Postes } & $\overline{\boldsymbol{x}}$ & 19,00 \\
\cline { 3 - 4 } & & $\boldsymbol{s}$ & 4,21 \\
\hline
\end{tabular}

\section{b. Analisis Data Pretes Kemampuan Komunikasi Matematik}

Analisis data pretes dilakukan dengan perhitungan uji perbedaan rataan data pretes kemampuan komunikasi siswa kelas eksperimen dan kelas kontrol menggunakan uji non parametik Mann Whitney. Hasilnya disajikan pada tabel 2.

Tabel 2 hasil uji perbedaan rataan pretes kemampuan komunikasi Matematik

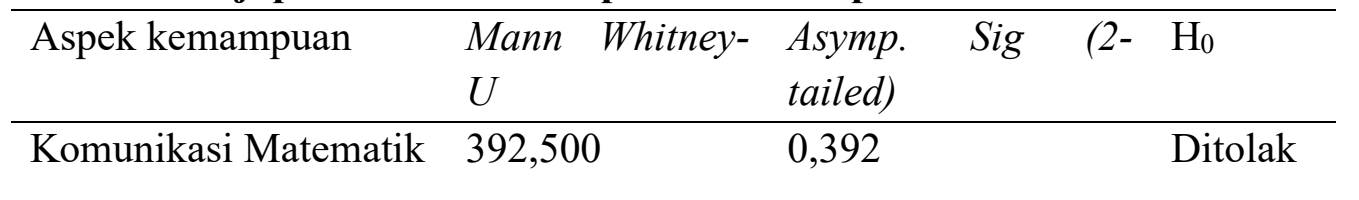

Hipotesis yang diuji untuk kemampuan awal matematik yaitu:

$\mathrm{H}_{0} \quad$ : kemampuan komunikasi matematik siswa kelas eksperimen tidak lebih baik dari atau sama dengan kelas kontrol

$\mathrm{H}_{1} \quad$ : kemampuan komunikasi matematik siswa kelas eksperimen lebih baik daripada kelas kontrol

Kriteria pengujian, jika nilai probabilitas (sig) lebih dari 0,05 , maka $\mathrm{H}_{0}$ diterima. Berdasarkan tabel 2 diatas, hipotesis nol diterima, sehingga hipotesis kedua atau $\mathrm{H}_{1}$ ditolak. Dengan demikian dapat disimpulkan bahwa kemampuan komunikasi matematik siswa kelas eksperimen tidak lebih baik dari kelas kontrol.

c. Analisis Data Postes Kemampuan Komunikasi Matematik Tabel 3Hasil Uji Perbedaan Rataan Postest Kemampuan Komunikasi Matematik 


\begin{tabular}{llll}
\hline Aspek kemampuan & Mann Whitney- & Asymp. Sig (2-tailed) & $\mathrm{H}_{0}$ \\
& $U$ & & \\
\hline Komunikasi Matematik & 251,500 & 0,003 & Diterima
\end{tabular}

Hipotesis yang diuji untuk kemampuan awal matematis yaitu:

$\mathrm{H}_{0} \quad$ : kemampuan komunikasi matematik siswa kelas eksperimen tidak lebih baik dari atau sama dengan kelas kontrol

$\mathrm{H}_{1} \quad$ : kemampuan komunikasi matematik siswa kelas eksperimen lebih baik daripada kelas kontrol.

Kriteria pengujian, jika nilai probabilitas (sig) lebih dari 0,05, maka $\mathrm{H}_{0}$ diterima. Berdasarkan tabel 3 diatas, hipotesis nol ditolak, sehingga hipotesis kedua atau $\mathrm{H}_{1}$ diterima. Dengan demikian dapat disimpulkan bahwa kemampuan komunikasi matematik siswa kelas eksperimenlebih baik dari kelas kontrol.

d. Analisis Data Pretes Self Confidence

Tabel 4 Hasil Uji Perbedaan Rataan Pretest Self Confidence

\begin{tabular}{|c|c|c|c|}
\hline $\begin{array}{ll}\text { Pernyataan } & \text { Self } \\
\text { Confidence } & \end{array}$ & $\begin{array}{l}\text { Mann Whitney- } \\
U\end{array}$ & $\begin{array}{l}\begin{array}{l}\text { Asymp. } \\
\text { tailed })\end{array}\end{array}$ Sig $\quad$ (2- & $\mathrm{H}_{0}$ \\
\hline 1 & 283,500 & 0,007 & ditolak \\
\hline 2 & 414,000 & 0,557 & diterima \\
\hline 3 & 435,000 & 0,809 & diterima \\
\hline 4 & 230,000 & 0,000 & ditolak \\
\hline 5 & 383,000 & 0,283 & diterima \\
\hline 6 & 291,000 & 0,007 & ditolak \\
\hline 7 & 388,500 & 0,329 & diterima \\
\hline 8 & 393,000 & 0,367 & diterima \\
\hline
\end{tabular}

Hipotesis yang diuji untuk kemampuan awal adalah:

$\mathrm{H}_{0}$ : kemampuan self confidence siswa kelas eksperimen tidak lebih baik dari atau sama dengan kelas kontrol

$\mathrm{H}_{1}$ : kemampuan self confidence siswa kelas eksperimen lebih baik daripada kelas kontrol.

Kriteria pengujian ini jika nilai signifikasi lebih dari 0,05 , maka $\mathrm{H}_{0}$ diterima dan $\mathrm{H}_{1}$ ditolak. Dan jika nilai signifikasi kurang dari 0,05 maka $\mathrm{H}_{0}$ ditolak dan $\mathrm{H}_{1}$ diterima.

Berdasarkan tabel 4 diatas maka:

Pernyataan 1 nilai signifikasi kurang dari 0,05 maka $\mathrm{H}_{0}$ ditolak dan $\mathrm{H}_{1}$ diterima, artinya kemampuan self confidence siswa kelas eksperimen lebih baik daripada kelas kontrol.

Pernyataan 2 nilai signifikasi lebih dari 0,05 maka $\mathrm{H}_{0}$ diterima dan $\mathrm{H}_{1}$ ditolak, artinya kemampuan self confidence siswa kelas eksperimen tidak lebih baik daripada kelas kontrol.

Pernyataan 3 nilai signifikasi lebih dari 0,05 maka $\mathrm{H}_{0}$ diterima dan $\mathrm{H}_{1}$ ditolak, artinya kemampuan self confidence siswa kelas eksperimen tidak lebih baik daripada kelas kontrol. 
Pernyataan 4 nilai signifikasi lebih dari 0,05 maka $\mathrm{H}_{0}$ diterima dan $\mathrm{H}_{1}$ ditolak, artinya kemampuan self confidence siswa kelas eksperimen tidak lebih baik daripada kelas kontrol.

Pernyataan 5 nilai signifikasi kurang dari 0,05 maka $\mathrm{H}_{0}$ ditolak dan $\mathrm{H}_{1}$ diterima, artinya kemampuan self confidence siswa kelas eksperimen lebih baik daripada kelas kontrol.

Pernyataan 6 nilai signifikasi lebih dari 0,05 maka $\mathrm{H}_{0}$ diterima dan $\mathrm{H}_{1}$ ditolak, artinya kemampuan self confidence siswa kelas eksperimen tidak lebih baik daripada kelas kontrol.

Pernyataan 7 nilai signifikasi kurang dari 0,05 maka $\mathrm{H}_{0}$ ditolak dan $\mathrm{H}_{1}$ diterima, artinya kemampuan self confidence siswa kelas eksperimen lebih baik daripada kelas kontrol.

Pernyataan 8 nilai signifikasi kurang dari 0,05 maka $\mathrm{H}_{0}$ ditolak dan $\mathrm{H}_{1}$ diterima, artinya kemampuan self confidence siswa kelas eksperimen lebih baik daripada kelas kontrol.

\section{e. Analisis Data Postes Self Confidence}

Tabel 5. Hasil Uji Perbedaan Rataan Pretest Self Confidence

\begin{tabular}{|c|c|c|c|}
\hline $\begin{array}{l}\text { Pernyataan Self } \\
\text { Confidence }\end{array}$ & Mann Whitney-U & $\begin{array}{l}\text { Asynp. Sig } \\
\text { tailed })\end{array}$ & $\mathrm{H}_{0}$ \\
\hline 1 & 297,500 & 0,016 & ditolak \\
\hline 2 & 316,000 & 0,034 & ditolak \\
\hline 3 & 255,000 & 0,002 & ditolak \\
\hline 4 & 295,500 & 0,015 & ditolak \\
\hline 5 & 304,500 & 0,016 & ditolak \\
\hline 6 & 293,000 & 0,015 & ditolak \\
\hline 7 & 323,000 & 0,047 & ditolak \\
\hline 8 & 308,000 & 0,027 & ditolak \\
\hline
\end{tabular}

Hipotesis yang diuji untuk kemampuan self confidence adalah:

$\mathrm{H}_{0}$ : kemampuan self confidence siswa kelas eksperimen tidak lebih baik dari atau sama dengan kelas kontrol

$\mathrm{H}_{1}$ : kemampuan self confidence siswa kelas eksperimen lebih baik daripada kelas kontrol.

Kriteria pengujian ini jika nilai signifikasi lebih dari 0,05 , maka $\mathrm{H}_{0}$ diterima dan $\mathrm{H}_{1}$ ditolak. Dan jika nilai signifikasi kurang dari 0,05 maka $\mathrm{H}_{0}$ ditolak dan $\mathrm{H}_{1}$ diterima. Berdasarkan tabel 4 diatas maka:

Pernyataan 1 sampai dengan 8 nilai signifikasi kurang dari 0,05 maka $\mathrm{H}_{0}$ ditolak dan $\mathrm{H}_{1}$ diterima, artinya setelah mendapat pembelajaran dengan menggunakan pendekatan realistik kemampuan self confidence siswa kelas eksperimen lebih baik daripada kelas kontrol.

\section{Pembahasan}


Pembahasan hasil penelitian ini disasarkan pada faktor-faktor yang dicermati dalam penelitian ini. Faktor-faktor tersebut adalah pembelajaran menggunakan pendekatan realistik dan self confidence siswa.

Berdasarkan analisis data hasil penelitian diperoleh bahwa siswa yang mendapatkan pembelajaran menggunakan pendekatan realistik berpengaruh terhadap kemampuan komunikasi matematik dan self confidence siswa.

Kelas yang mendapatkan pembelajaran dengan menggunakan pendekatan realistik telah berjalan sesuai dengan harapan. Berikut ulasan mengenai pelaksanaan penelitian yang dilakukan:

1. Sebelum memulai pembelajaran, peneliti terlebih dahulu membagi kelompok secara heterogen terdiri dari 5-6 orang. Setelah seluruh siswa mendapatkan kelompok, peneliti membagikan LKS yang harus dikerjakan oleh masing-masing kelompok.

2. Peneliti memberi petunjuk untuk mengisi LKS tersebut. LKS yang diberikan berbentuk kontekstual sehingga akan memudahkan siswa untuk mengerjakannya.

3. Setelah selesai mengerjakan LKS tersebut, peneliti meminta salah satu perwakilan dari kelompok untuk menuliskan hasil diskusi bersama kelompoknya, kelompok lain memperhatikan dan dipersilahkan untuk memberi masukan atau menyanggah tentang apa yang didapatkan oleh kelompok lain sehingga terjadi diskusi. Dalam hal ini self confidence siswa akan terlihat simana mengeluarkan ide-ide dan pendapat yang mereka miliki.

4. Setelah diskusi selesai, peneliti melakukan refleksi dan evaluasi terhadap persoalan pada LKS dengan membimbing siswa memahami konsep matematika formal.

Untuk mengetahui hasil belajar siswa dari dua kelas yang menjadi sampel penelitian, maka diberikan pretes dan pstes. Pretes diberikan sebelum pembelajaran, bertujuan untuk melihat kemampuan awal siswa tentang kemampuan komunikasi dan self confidence berkenaan dengan materi yang diberikan. Pada tes awal yang dilakukan (pretes) perbedaan kemampuan komunikasi yang diperoleh kedua kelas tidak begitu terlihat atau dengan kata lain kemampuan komunikasi matematik siswa relatif sama. Ini dapat dilihat pada tabel. 1.

Setelah mendapatkan pembelajaran yang berbeda selama 8 kali pertemuan, maka diadakan postes di kelas eksperimen dan kelas kontrol. Postes diberikan bertujuan untuk mengetahui sejauh mana perkemangan kemampuan komunikasi matematik dan self confidence siswa. hasil rata-rata postes yang didapat dapat dilihat pula di tabel 1 .

Untuk analisis kemampuan komunikasi dari data hasil pretes dan postes dilakukan dikedua kelas, terdapat peningkatan kemampuan komunikasi pada kelas ekspermen. Dimana pada saat pretes menurut perhitungan menggunakan uji Man Whitney kemampuan komunikasi matematik siswa kelas eksperimen tidak lebih baik dari atau sama dengan kelas kontrol.

Namun setelah kelas eksperimen memperoleh pembelajaran dengan pendekatan realistik, pada hasil postes terdapat perubahan yaitu kemampuan komunikasi matematik siswa kelas eksperimen lebih baik dari pada kelas kontrol. 
Begitu juga dengan kemampuan self confidence siswa, pada saat pretes lebih dominan siswa kelas eksperimen tidak lebih baik dari atau sama dengan kelas kontrol. Dan pada saat postes kelas eksperimen memiliki kemampuan self konfidence lebih baik dibandingkan dengan kelas kontrol.

\section{KESIMPULAN}

Dari uraian pembahasan diatas dapat disimpulkan bahwa:

1. Kemampuan komunikasi matematik siswa yang memperoleh pembelajaran dengan pendekatan realistik lebih baik daripada siswa yang memperoleh pembelajaran biasa.

2. Kemampuan self confidence siswa yang memperoleh pembelajaran dengan pendekatan realistik lebih baik daripada siswa yang memperoleh pembelajaran biasa.

\section{DAFTAR PUSTAKA}

Haji, S. (2012).Pengaruh Pembelajaran Kontekstual Terhadap Kemampuan Komunikasi Matematika Siswa SMP Kota Bengkulu.Jurnal Exacta.Vol.X.

Hendriana, H. (2014). Membangun kepercayaan diri siswa melalui pembelajaran matematika humanis. Jurnal Pengajaran MIPA, 19(1), 52-60.

Hendriana, H., Sumarmo, U., \& Rohaeti, E. E. (2013). Kemampuan Komunikasi Matematik serta Kemampuan dan Disposisi Berpikir Kritis Matematik. Jurnal Matematika dan Pendidikan Matematika, Vol. 2, No. 1.

Hidayat, W. (2017). Adversity Quotient dan Penalaran Kreatif Matematis Siswa SMA dalam Pembelajaran Argument Driven Inquiry pada Materi Turunan Fungsi. KALAMATIKA Jurnal Pendidikan Matematika, 2(1), 15-28.

Rosita, N. T. (2017). Implementasi Pembelajaran Matematika dengan Pendekatan Open Ended terhadap Sikap Siswa. Symmetry: Pasundan Journal of Research in Mathematics Learning and Education, 1(1), 1-12.

Rosyana, T., \& Sari, I. P. (2015). Penerapan Aktivitas Quick On The Draw Melalui Pendekatan Thinking Aloud Pair Problem Solving Untuk Meningkatkan Kemampuan Komunikasi dan Penalaran Matematis Siswa MA. UPT P2M STKIP Siliwangi, Vol. 2, No.2.

Ruseffendi, E.T. (2010). Dasar-Dasar Penelitian Pendidikan \& Bidang Non-Eksakta Lainnya. Bandung: Tarsito.

Suparno (2001).Membangun Kompetensi Belajar. Jakarta: Dirjen Dikti Depdiknas. 